\title{
Microstructural, thermochemistry and mechanical evaluation of self-reducing pellets using electric arc furnace (EAF) dust containing zinc for Waelz process
}

\author{
Leidy Julieth Hernández Buitrago ${ }^{1}$, Iván Daza Prada ${ }^{1,}$ Gisele Amaral-Labat ${ }^{1}$ \\ Flávio Beneduce Neto ${ }^{1}$, Guilherme Frederico Bernardo Lenz e Silva ${ }^{1}$
}

\footnotetext{
${ }^{1}$ Department of Metallurgical and Materials Engineering - Laboratory of High Energy Grinding, Carbon and Composite

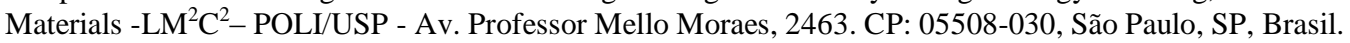
e-mail: leidy011@usp.br, gisele.amaral@usp.br; guilhermelenz@usp.br
}

\begin{abstract}
The increment of recycling of steel using electric arc furnace and the tendency to coat of steel products with zinc, in order to prevent corrosion, has increased the proportion of galvanized scrap used worldwide in the recent years. Approximately 10 to $20 \mathrm{Kg} / \mathrm{t}$ of cast steel is generated in casting arcs. These collected dusts electric arc furnace (EAF dust) contains iron, zinc, lead, and cadmium. Mainly in the form of oxides and their wastes are considered hazardous typically in countries such as Brazil, U.S., Japan and Germany. It is estimated that from the total of 7.5 million metric tons of EAF dust generated worldwide only $45 \%$ is recycled. With Waelz process, the EAF dust can be treated to recover zinc by means of reductionvolatilization-oxidation reactions occurring within the rotary kiln. In this work the thermodynamics of the Waelz process is studied to optimize the recovery of volatiles especially zinc. Kinetic parameters were evaluated trough series of ten experiments, comprise the major process factors such as type of reductants (charcoal and petroleum coke), time $\left(20-120\right.$ minutes) and temperature $\left(450-1150^{\circ} \mathrm{C}\right)$. The mechanical behavior of the pellets was evaluated by compressive cold strength and drop tests. Characterization was performed using scanning electron microscopy, microanalysis EDS, X-ray diffraction, X-ray fluorescence, granulometric analysis by laser diffraction, as well as measurements of moisture, bulk density and percentage of volatiles, fixed carbon and ash. The small pellets $(10 \mathrm{~mm})$ with charcoal used as a reductant, presented a higher compression and higher recovery of volatiles than those with petroleum coke.
\end{abstract}

Keywords: Self-reducing pellets; recovery of zinc; treatment of steelmaking waste; Waelz process.

\section{INTRODUCTION}

Nowadays, environmental sustainability has been led to improve new development focusing recycling and use of metals contained in several residues from metallurgical industry. Zinc is the third most widely used non-ferrous metal in the world and therefore is present in great quantity of wastes from metallurgical processes. Furthermore, the final applications of zinc based materials including galvanized products (corrosion protection), copper alloys, batteries, agriculture and cosmetics [1,2].

Primary sources of zinc are sulphide and oxidized ores, such as: sphalerite - ( $\mathrm{Zn}, \mathrm{Fe}) \mathrm{S}$; zinc carbonate - $\mathrm{ZnCO}_{3}$; zinc silicate - $\mathrm{Zn}_{2}\left(\mathrm{SiO}_{4}\right)$ and franklinite - $\left(\mathrm{ZnFe}_{2} \mathrm{O}_{4}\right)$. In 2015, for example, were produced $13,400,000$ metric tons of ores, equivalent to more than 100,000 metric tons of refined zinc [1]. On the other hand, there is also a search of reprocessing of secondary sources, such as waste from the galvanizing industry and recycling of dusts from electric arc furnace.

One of the main secondary sources of zinc, are the dust of the particulate removal systems of electric arc furnace - EAF. Approximately 10 to $20 \mathrm{~kg}$ of dust from non-integrated steelworks using electric arc furnace are generated for each ton of steel manufactured [2]. In 2014, the world steel production via EAF generated about of 8,100,000 metric tons of waste containing approximately 1,700,000 metric tons of zinc [3].

Zinc recycling results in environmental, social and economic benefits, including the decreasing of several relevant factors: (i) atmospheric emissions and air pollutants; (ii) save energy and (iii) solid waste generation. The controlled deposition, or not, of waste from the electric steelworks (powders and fine dust from de-dusting system) causes various environmental impacts. These materials are classified by toxic and 
dangerous, as much in Brazil NBR 10004 standard (ABNT, 2004) [5], as in other countries like US-EPA (Environmental Protection Agency, 1998) [6], Japan and Germany (GMDI 170, 1990) [7].

Dust and powders collected in the de-dusting systems from the EAF is primarily composed by iron and zinc oxides, followed by lead, copper, nickel, calcium and magnesium oxides. The iron might be present as magnetite $\left(\mathrm{Fe}_{3} \mathrm{O}_{4}\right)$, wustite $(\mathrm{FeO})$, hematite $\left(\alpha-\mathrm{Fe}_{2} \mathrm{O}_{3}\right.$ and/or $\left.\gamma-\mathrm{Fe}_{2} \mathrm{O}_{3}\right)$ or in its metallic form (Fe) [8] while zinc is found in its metallic form $\left(\mathrm{Zn}_{(\mathrm{s})}\right)$, zinc oxide $\left(\mathrm{ZnO}_{(\mathrm{s})}\right)$ and zinc ferrite $\left(\mathrm{ZnO} \cdot \mathrm{Fe}_{2} \mathrm{O}_{3(\mathrm{~s})}\right)$.

From the industrial point of view, the Waelz process is the oldest method and the main recycling route of waste from electric steelworks containing zinc, representing 5.2\% of the world production of refined zinc [4]. The Waelz process, which process schema is shown in figure 1, is a pyrometallurgical method, characterized by the volatilization of nonferrous metals like zinc, lead and cadmium, from a solid mix (EAF dust + binder + reductant + water). Such mixing is reduced by coal or petroleum coke (reductants), in a rotary kiln without generating liquid slag. The EAF dust is then converted in Waelz oxide, and later taken to refineries for recovering the zinc metallic.

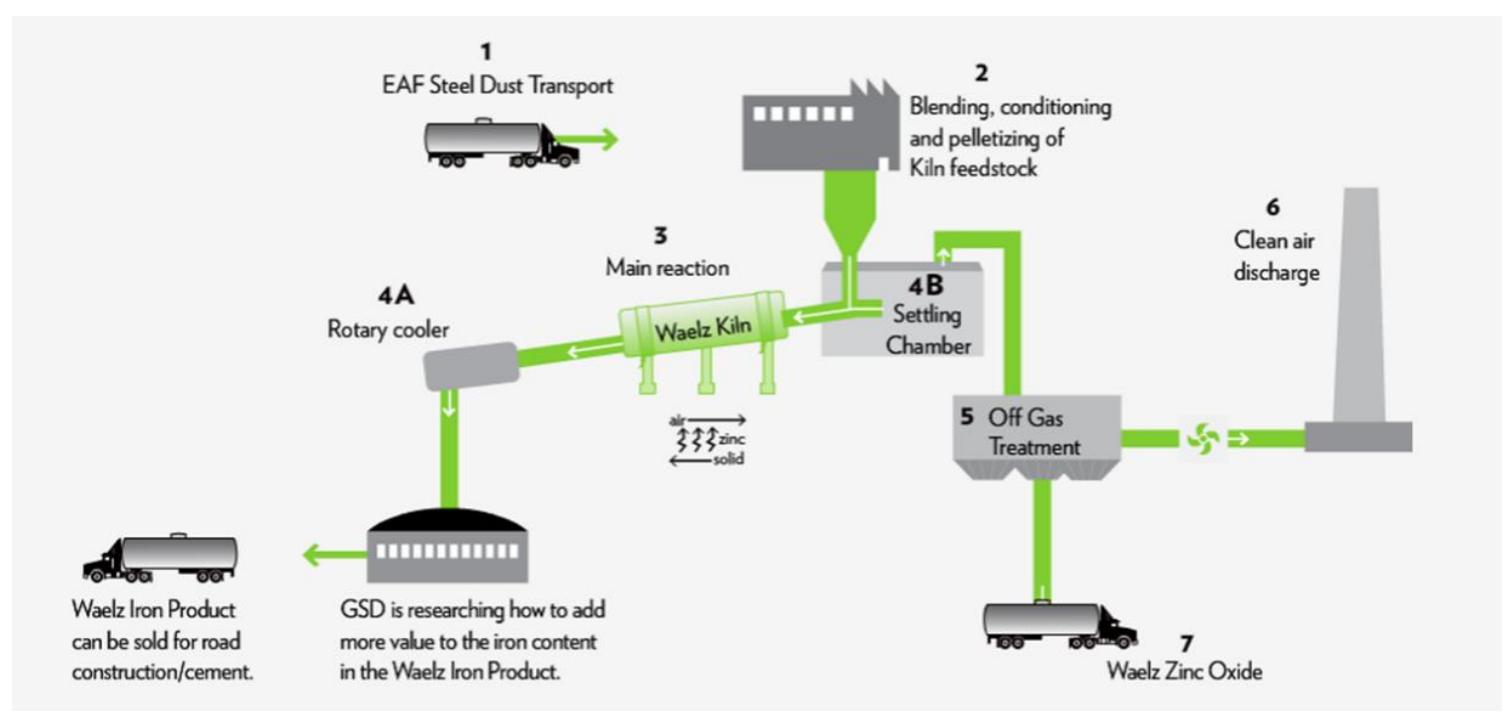

Figure 1: Typical Waelz process schema (recycling of dusts and residues containing zinc), from [9].

Despite the significant cost of carbon reductants (coal and/or coke) used in the high Waelz process, the low cost of raw materials and energy, as well as the relevant zinc price, make the process profitable $[4,11]$. Therefore, the reduction of zinc oxide contained in EAF dust is usually prepared using carbon as reductant, releasing carbon monoxide (carbothermic reduction), to assist in the sequential reduction reactions of the process [12].

Although there are other technological alternatives for the treatment of residues containing zinc, such as: hydrometallurgical processes, Mitsui furnace, electrothermal recovery, via Daido furnace and Primus, among others. Besides, hydrometallurgical processes can cause secondary residues simultaneously [14] and serious problems of leaching contamination due to halogens contained in EAF dust. [15]. Thus, the Waelz recycling process remains the predominant method for powder processing, covering approximately $85 \%$ of the market. The Waelz process is a recycling route with low energy consumption, high reliability, and high recovery rates, since values of up to $95 \%$ are achieved depending on the process parameters [4]. This process has been the preferred option for the recycling of EAF dust and remains the only one to have achieved commercialization [13].

\subsection{Carbothermic Reduction}

Studies of morphology performed in synthetic dust, reduced by carbothermic way, showed the decomposition to oxides $\left(\mathrm{ZnO}\right.$ and $\left.\mathrm{Fe}_{2} \mathrm{O}_{3}\right)$, between 800 to $1000^{\circ} \mathrm{C}$ and a sequential reduction of both zinc and iron oxides $[16,17]$. Similarly, in an inert atmosphere, the pure zinc ferrite is preferentially decomposed to $\mathrm{ZnO}$ and $\mathrm{Fe}_{2} \mathrm{O}_{3}$ [18] as shown in reaction 1. The changes involved in the reduction of zinc oxide in EAF powder with iron powder are described in equations 1 to 5 . 


$$
\mathrm{ZnO} \cdot \mathrm{Fe}_{2} \mathrm{O}_{3(\mathrm{~s})}=\mathrm{ZnO}_{(\mathrm{s})}+\mathrm{Fe}_{2} \mathrm{O}_{3(\mathrm{~s})}
$$

After the decomposition reaction, the $\mathrm{Fe}_{2} \mathrm{O}_{3}$ is reduced to $\mathrm{Fe}$ with the following overall reaction 2:

$$
\mathrm{Fe}_{2} \mathrm{O}_{3(\mathrm{~s})}+3 \mathrm{C}_{(\mathrm{s})}=2 \mathrm{Fe}_{(\mathrm{s} / \mathrm{l})}+3 \mathrm{CO}(\mathrm{g})
$$

The intermediate reactions are described by the following reactions (3-5) in the temperature range between $700-1200^{\circ} \mathrm{C}[14]$. It is worth mentioning that the $\mathrm{p}_{\mathrm{CO}} / \mathrm{p}_{\mathrm{CO} 2}$ ratio must be defined by Boudouard reaction:

$$
\begin{aligned}
& 3 \mathrm{Fe}_{2} \mathrm{O}_{3(\mathrm{~s})}+\mathrm{CO}(\mathrm{g})=2 \mathrm{Fe}_{3} \mathrm{O}_{4(\mathrm{~s})}+\mathrm{CO}_{2(\mathrm{~g})} \\
& \mathrm{Fe}_{3} \mathrm{O}_{4(\mathrm{~s})}+\mathrm{CO}(\mathrm{g})=3 \mathrm{FeO}_{(\mathrm{s})}+\mathrm{CO}_{2} \\
& \mathrm{FeO}_{(\mathrm{S})}+\mathrm{CO}(\mathrm{g})=\mathrm{Fe}(\mathrm{s}) \\
& \mathrm{CO}_{2(\mathrm{~g})}
\end{aligned}
$$

At the same time, at low temperatures, zinc oxide $(\mathrm{ZnO})$ is reduced to liquid zinc according reaction 6.

$$
\left.\mathrm{ZnO}_{(\mathrm{s})}+\mathrm{CO}_{(\mathrm{g})}=\mathrm{Zn}_{(\mathrm{l} / \mathrm{g}}\right)+\mathrm{CO}_{2(\mathrm{~g})}
$$

At high temperatures, zinc is vaporized (Reaction 6) and the amount of zinc in the gas phase is described by equation (7). Where $\mathrm{K}$ is the equilibrium constant and $\mathrm{p}_{\mathrm{Zn}}$, is the partial pressure of zinc vapor.

$$
\left(\mathrm{p}_{\mathrm{Zn}} * \mathrm{p}_{\mathrm{CO} 2}\right) / \mathrm{P}_{\mathrm{CO}}=\mathrm{K}
$$

The carbothermic reduction of zinc oxide has been studied between 127 to $1973^{\circ} \mathrm{C}$. However, the zinc reduction occurs around $927^{\circ} \mathrm{C}$ in two distinct steps: (i) reduction reaction of zinc oxide (Reaction 6), and (ii) Boudouard reaction (Reaction 8) [19]. The Figure 2 shows, the $\mathrm{p}_{\mathrm{CO}} / \mathrm{p}_{\mathrm{CO} 2}$ ratio versus temperature at various $\mathrm{p}_{\mathrm{CO}}$ and the reduction of $\mathrm{ZnO}$ with carbon, for total pressure of $1 \mathrm{~atm}$.

$$
\mathrm{C}_{(\mathrm{s})}+\mathrm{CO}_{2(\mathrm{~g})}=2 \mathrm{CO}_{(\mathrm{g})}
$$

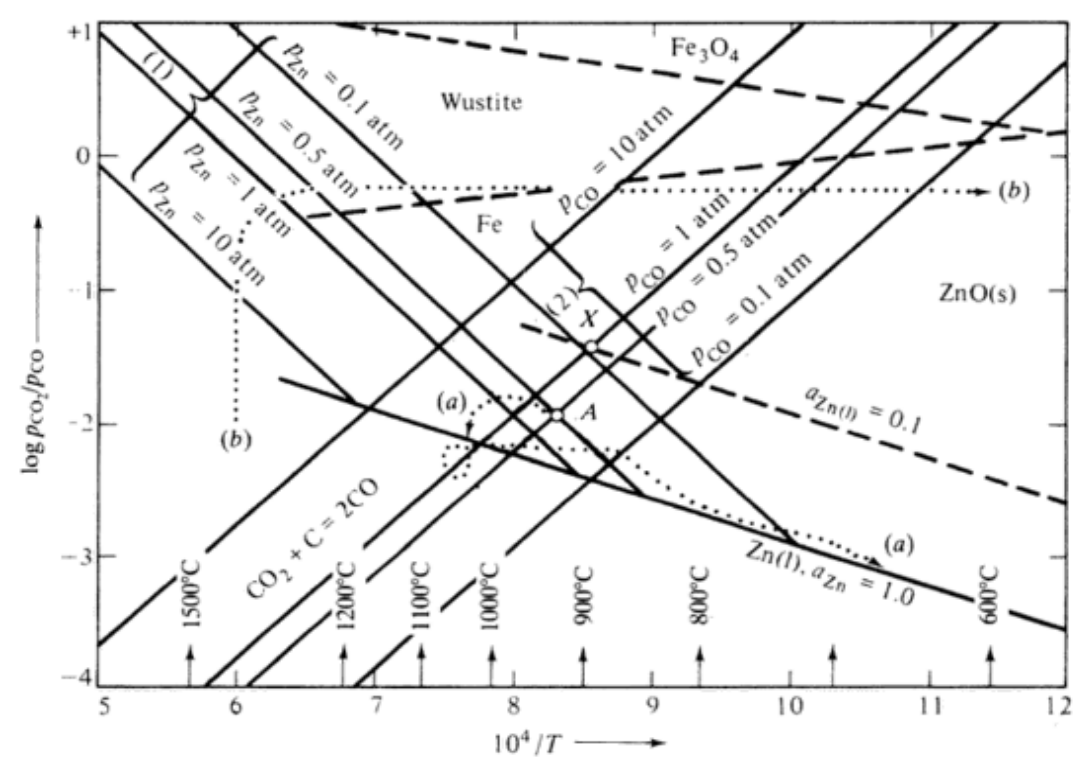

Figure 2: Equilibrium gas ratios for reduction of $\mathrm{ZnO}_{(\mathrm{s})}$ to $\mathrm{Zn}_{(\mathrm{l})}$ as well as to $\mathrm{Zn}_{(\mathrm{g})}$ including the Boudouard reaction [20].

A treatment of a synthetic zinc ferrite was carried out in a TGA (thermal gravimetric apparatus) with argon flow to simulate the sequential kinetics of the reactions of reduction [17]. It was proposed that initially the zinc ferrite decomposes to the $\mathrm{ZnO}$ and $\mathrm{Fe}_{2} \mathrm{O}_{3}$ oxides. Those oxides are reduced by carbothermic reduction and the zinc produced from the reduction of $\mathrm{ZnO}$ release immediately in gaseous form, while the $\mathrm{Fe}_{2} \mathrm{O}_{3}$ is reduced through the sequence $\mathrm{Fe}_{2} \mathrm{O}_{3} \rightarrow \mathrm{Fe}_{3} \mathrm{O}_{4} \rightarrow \mathrm{FeO} \rightarrow \mathrm{Fe}$, confirming the above equations [17]. Hong, Sohn, \& Sano [19]. found an activation energy for carbothermic reduction of zinc oxide between 800 and 
$900^{\circ} \mathrm{C}$ of $222 \mathrm{~kJ} / \mathrm{mol}$ [14], while Osinga, Olalde and Steinfeld [16] obtained an apparent activation energy of $201.5 \mathrm{~kJ} / \mathrm{mol}$.

For further optimization of treatment of EAF dust, pyrometallurgical recycling of EAF dust has to confront the challenges related to several factors; the complex occurrence as the association of various metallic phases in the dust, the reoxidation of non-ferrous metals after reduction, and the enrichment of hazardous impurities in the generated fume and residue. In order to solve those issues, a detailed exploration of the metallic phases in the dust based on thermodynamic and kinetics analysis was performed. [21].

\section{MATERIALS AND METHODS}

\subsection{Preparation of the self-reduced pellets}

The EAF dust and the reductants have dried at $140^{\circ} \mathrm{C}$ overnight before their homogenization in a mixer Turbula WAB. The pellets were then prepared manually through the mixture of EAF dust, coal or petroleum coke as a reducer, $\mathrm{Ca}(\mathrm{OH})_{2}$, sugar cane molasses as a binder agent and water. After its manufacture, the pellets were stored in an oven at $100^{\circ} \mathrm{C}$ to prevent moisture. They had a diameter of $10 \mathrm{~mm}$ for carbothermic reduction tests and for compressive strength measurements. For drop test, pellets with three different diameters have been produced $(15.0 ; 10.0$ and $7.5 \mathrm{~mm}$ ). The drop test for green pellets (with different curing times (drying): 1, 3, 7 and 14 days) was tested individually by dropping them from heights of $0.5 ; 1.0 ; 1.5$ and 2.0 $\mathrm{m}$ on a ceramic tile. Five replicates were used for each test.

\subsection{Carbothermic reduction of EAF dust}

The experiments conditions are presented in Table 1. The isothermal reduction of pellets was divided in a series of 10 experiments, prepared in a tubular furnace under argon flow $\left(0.20 \mathrm{~m}^{3} / \mathrm{h}\right)$. The mass loss was measured using an electronic scale with the sample suspended by a stainless steel wire, as shown in Figure 3. The pellets were individually reduced while time was measured until the stabilization of the mass loss, caused by the removal of volatiles. Afterwards, sample was cold for 20 minutes under argon flow $\left(0.40 \mathrm{~m}^{3} / \mathrm{h}\right)$ and then removed of the oven for subsequent analysis.

Table 1: Design of experiments.

\begin{tabular}{|c|c|c|c|c|}
\hline EXPERIMENTS & $\begin{array}{l}\text { EAF DUST } \\
\text { AMOUNT } \\
\text { wt } \%\end{array}$ & $\begin{array}{l}\text { BINDER } \\
\text { wt } \% \\
\left(\mathrm{Ca}(\mathrm{OH})_{2}+\right. \\
\text { sugar cane } \\
\text { molasse })\end{array}$ & $\begin{array}{l}\text { REDUCTANT } \\
\text { wt } \%\end{array}$ & $\begin{array}{l}\text { TEMPERATURE } \\
\left({ }^{\circ} \mathrm{C}\right)\end{array}$ \\
\hline 1 & \multirow{5}{*}{78.9} & \multirow{5}{*}{4} & \multirow{5}{*}{$\begin{array}{l}\text { Charcoal } \\
13.1\end{array}$} & 450 \\
\hline 2 & & & & 650 \\
\hline 3 & & & & 800 \\
\hline 4 & & & & 1050 \\
\hline 5 & & & & 1150 \\
\hline 6 & \multirow{5}{*}{79.9} & \multirow{5}{*}{4} & \multirow{5}{*}{$\begin{array}{l}\text { Petroleum coke } \\
12.1\end{array}$} & 450 \\
\hline 7 & & & & 650 \\
\hline 8 & & & & 800 \\
\hline 9 & & & & 1050 \\
\hline 10 & & & & 1150 \\
\hline
\end{tabular}




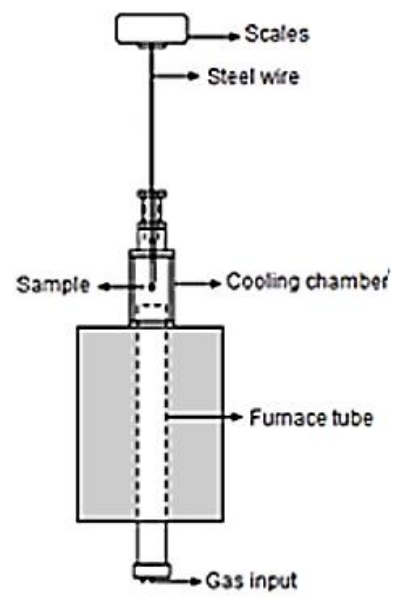

Figure 3: Experimental apparatus for carbothermic reduction tests

\subsection{Characterization methods}

The initial raw-material EAF dust and the reduced pellets were analysed by a DRX Bruker difratometer with $(\mathrm{Cu} \mathrm{K} \alpha \lambda$ : $1.54178 \AA$; using a scan rate of $0.02 \%)$. The chemical composition was evaluated in spectrometer $\mathrm{X}$-ray fluorescence (calibration STD-1). The particle size distribution analysis was performed by a laser granulometer Helos.

All samples were observed at different magnifications with a CambridgeStereoscan scanning electron microscope (SEM). The semi quantitative chemical evaluation was performed using energy dispersive X-ray spectroscopy (EDX) to evaluate the zinc content before and after the carbothermic reduction in temperatures of 450 to $1150^{\circ} \mathrm{C}$. The mechanical properties (compression) of the samples were tested, according to ASTM E382 - 12 "Standard Test Method for Determination of Crushing Strength of Iron Ore Pellets" [25] using a KRATOS universal testing machine equipped with a $50 \mathrm{kgf}$ head. The compression was carried out at a constant load velocity of $4 \mathrm{~mm} / \mathrm{min}$.

Charcoal and petroleum coke were used as reductants. Each reductant were ground and sieved to a same size particle $\left(\mathrm{D}_{50}\right.$ of $\left.13.2 \mu \mathrm{m}\right)$, in order to eliminate the influence of such variable in the self-reduction process. The proximate analysis of the reductants were prepared according to ASTM D3174-11 "Standard Test Method for Ash in the Analysis Sample of Coal and Coke from Coal" [26], ASTM D3173-11 "Standard Test Method for Moisture in the Analysis Sample of Coal and Coke" [27] e ASTM D3175-11 "Standard Test Method for Volatile Matter in the Analysis Sample of Coal and Coke" [28] and are shown in table 2. The procedure for carrying out the immediate analyzes of EAF were adapted from the ASTM standards used in the immediate analyzes for charcoal and petroleum.

Table 2: Chemical analysis and characteristics of the reductants.

\begin{tabular}{c|c|c|c|c}
\hline REDUCTANT & MOISTURE(\%) & VOLATILES(\%) & ASH(\%) & $\begin{array}{l}\text { FIXED } \\
\text { CARBON(\%) }\end{array}$ \\
\hline Charcoal & $5.09 \pm 0.10$ & $30.23 \pm 1.00$ & $0.77 \pm 0.26$ & $69.00 \pm 0.52$ \\
\hline Petroleum coke & $1.20 \pm 0.10$ & $11.25 \pm 0.24$ & $14.37 \pm 0.17$ & $74.38 \pm 0.05$ \\
\hline
\end{tabular}




\section{RESULTS}

\subsection{Characterization of Raw Material}

The EAF dust used in the present study was kindly supplied by Votorantim-Brazil. A complete characterization of the raw material was performed and is shown in table 3 .

Table 3: Complete characterization of the raw EAF dust.

\begin{tabular}{ll|l|l|l|l|l}
\hline $\begin{array}{l}\text { MOISTURE } \\
(\mathrm{wt} \%)\end{array}$ & $\begin{array}{l}\text { MASS } \\
\text { LOSS }(\%)\end{array}$ & $\begin{array}{l}\text { VOLATILE } \\
\mathrm{S}(\%)\end{array}$ & $\begin{array}{l}\text { GRANULOMETRY } \\
(\mu \mathrm{m})\end{array}$ & \multicolumn{2}{|l}{$\begin{array}{l}\text { COMPOSITION BASED ON } \\
\text { XRF ANALYSIS }\end{array}$} \\
\hline 0.011 & \pm & 14.50 & $11.24 \pm 1.20$ & $0.12-50.00$ & Element & $\mathrm{Wt}(\%)$ \\
\cline { 5 - 6 } 0.001 & & & $\mathrm{D}_{50}$ of $2.90 \mu \mathrm{m}$ & Iron $\left(\mathrm{Fe}^{3+}\right)$ & 37.50 \\
\cline { 4 - 6 } & & & & $\mathrm{Zn}$ & 19.40 \\
\end{tabular}

The main phases presented X-ray diffraction are $\mathrm{ZnO} . \mathrm{Fe}_{2} \mathrm{O}_{3}$ (franklinite) and $\mathrm{Fe}_{2} \mathrm{O}_{3}$ (hematite), besides other phases in a lesser proportion such as $\mathrm{ZnO}, \mathrm{Zn}, \mathrm{SiO}_{2}$, and other oxides in a fewer amount. The Figure 3 present the XRD diffractogram of raw EAF

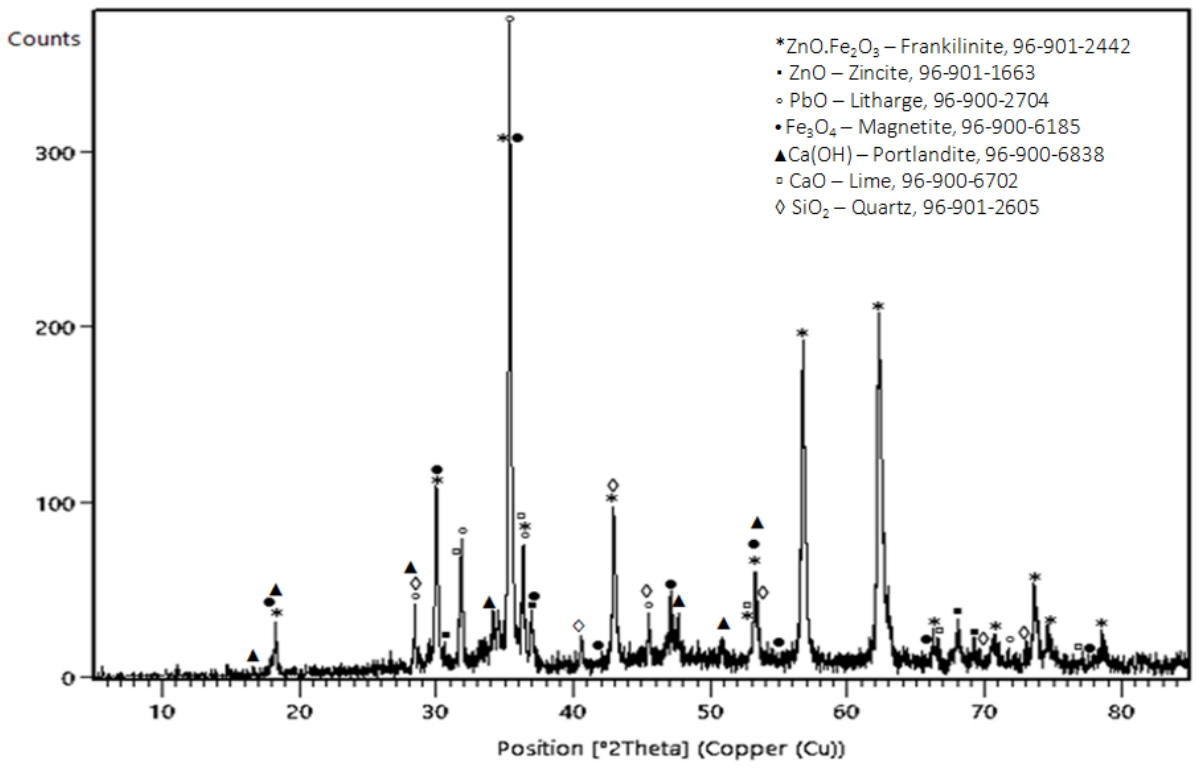

Figure 4: XRD pattern of EAF dust. 


\subsection{Microstructural evaluation of self-reducing pellets of EAF dust at temperatures from 450 to $1150^{\circ} \mathrm{C}$}

Figures 5 and 6 show the SEM pictures of reduced pellets with charcoal and petroleum coke, respectively, from 450 to $1150^{\circ} \mathrm{C}$.

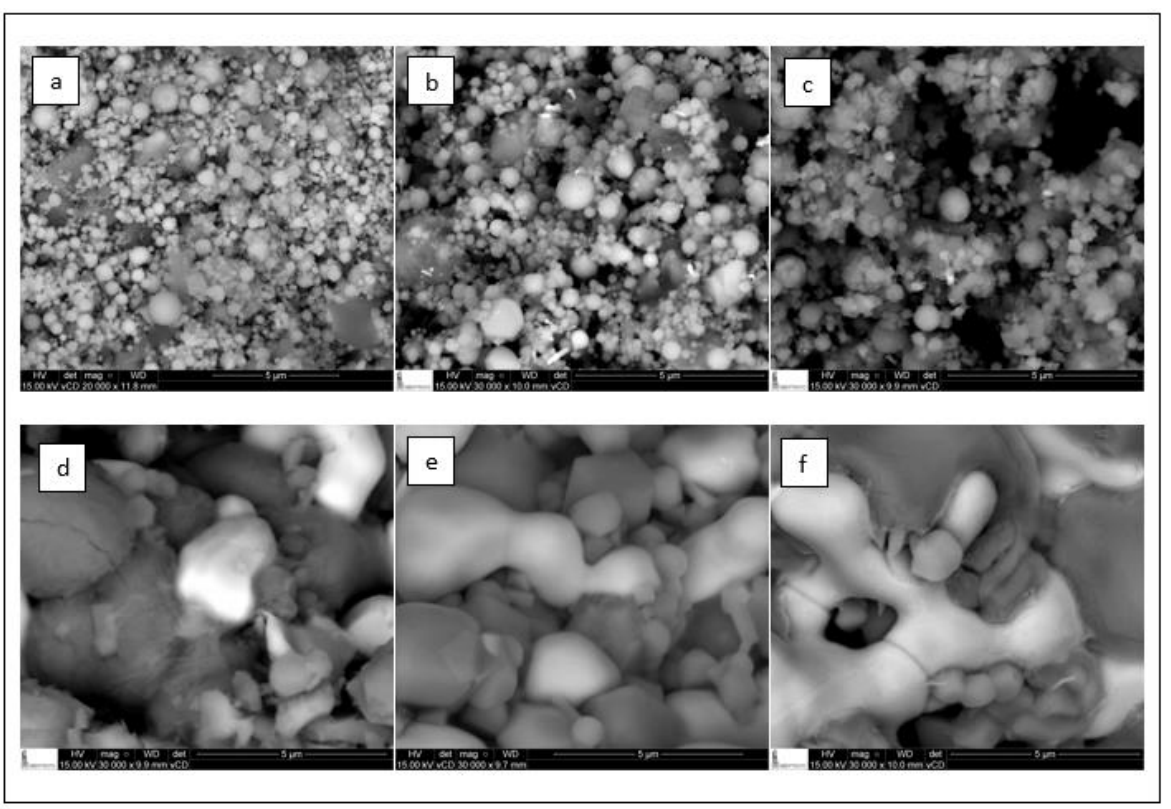

Figure 5:SEM images of EAF dust pellets reduced with charcoal: a) raw pellet, b), c), d), e) and f) reduced pellets at $450{ }^{\circ} \mathrm{C}, 650{ }^{\circ} \mathrm{C}, 800{ }^{\circ} \mathrm{C}, 1050^{\circ} \mathrm{C}$ and $1150^{\circ} \mathrm{C}$ respectively.

Figure 5-b shows that the typical spherical morphology of particles from EAF dust, reduced at $450^{\circ} \mathrm{C}$ are still present on the pellet from the agglomerated state. The EDX results, indicated the presence of iron, zinc, calcium and oxygen. For pellets reduced at $650{ }^{\circ} \mathrm{C}$, the particles began to lose the round aspect becaming slight amorphic, thinner and agglomerated (Figure 5c). A relevant change in chemical composition was not found compared to the previous temperature, however brightest and clearer particles composed basically of lead are clearly seen. The particles presented in pellets reduced at $800^{\circ} \mathrm{C}$ show the beginning of a coalescing state and an increasing amount of lead particles, while at $1050^{\circ} \mathrm{C}$ (Figure $5 \mathrm{~d}$ ) particles are in a state of merger due to an amorphous appearance. Lead particles are not found because of the melting temperature of lead oxide $\left(888^{\circ} \mathrm{C}\right)$ and the EDX analysis indicated the presence of iron, calcium and oxygen once zinc was volatilized. Finally, at $1150^{\circ} \mathrm{C}$ particles size is clearly increased showing their melting and coalescing. The chemical composition showed that the lighter phase is rich in iron, while the light and dark gray phases are mainly composed of calcium and magnesium. 


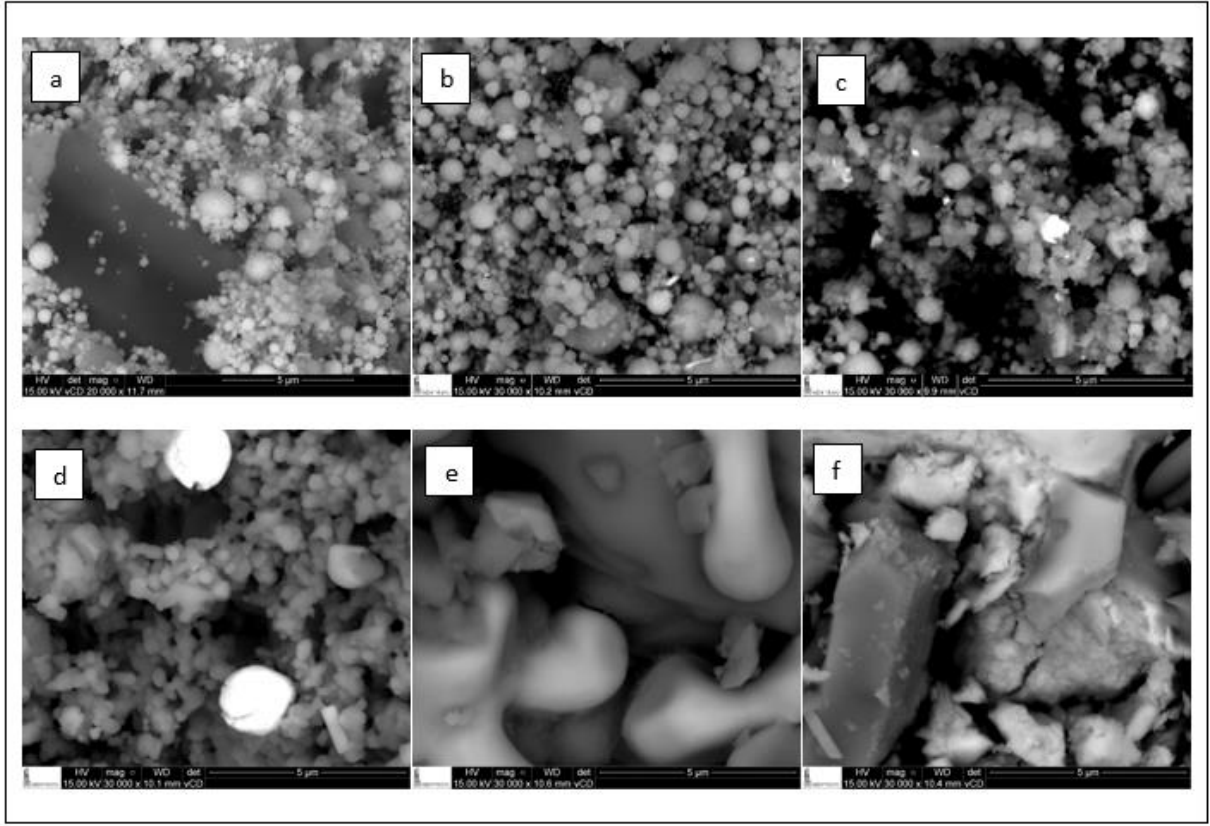

Figure 6: SEM images of EAF dust pellets reduced with petroleum coke: a) raw pellet, b), c), d), e) and f) reduced pellets at $450^{\circ} \mathrm{C}, 650^{\circ} \mathrm{C}, 800^{\circ} \mathrm{C}, 1050^{\circ} \mathrm{C}$ and $1150^{\circ} \mathrm{C}$ respectively.

The pellets reduced with petroleum coke presented the similar behavior of those reduced with charcoal although in a lower rate. Structural changes occurred due to the increase in temperatures of carbothermic reductions are shown in Figure 7. The phases formed are independent of the reductant used, since changes are dependent on the stoichiometric calculations and on conditions of the self-reduction process.

The XRD pattern in figure 7 has shown that at $450^{\circ} \mathrm{C}$, main and secondary phases are composed by $\mathrm{Fe}_{2} \mathrm{O}_{4}, \mathrm{ZnO}, \mathrm{ZnFe}_{2} \mathrm{O}_{4}$ and $\mathrm{MgO}, \mathrm{Ca}(\mathrm{OH})_{2}, \mathrm{SiO}_{2}$, respectively. At $650^{\circ} \mathrm{C}$ phases of $\mathrm{Fe}_{2} \mathrm{O}_{4}, \mathrm{FeO}, \mathrm{ZnFe}_{2} \mathrm{O}_{4}$, and $\mathrm{ZnO}$ are identified, followed by smaller proportions of $\mathrm{MgO}, \mathrm{CaO}$ e $\mathrm{SiO}_{2}$. Increasing the temperature to $800^{\circ} \mathrm{C}$ zinc is present as $\mathrm{ZnFe}_{2} \mathrm{O}_{4}, \mathrm{ZnO}$ and $\mathrm{Zn}^{\circ}$, iron is found as $\mathrm{Fe}_{3} \mathrm{O}_{4}$ and $\mathrm{Fe}^{\circ}$, besides small amounts of $\mathrm{MgO}, \mathrm{CaO}$ and $\mathrm{SiO}_{2}$. At $1050^{\circ} \mathrm{C}$, most of zinc and iron oxides are reduced. The phases present at this temperature are majority composed of metallic iron and $\mathrm{FeO}$, followed by $\mathrm{MgO}, \mathrm{CaO}$ and $\mathrm{SiO}_{2}$ as secondary phases.

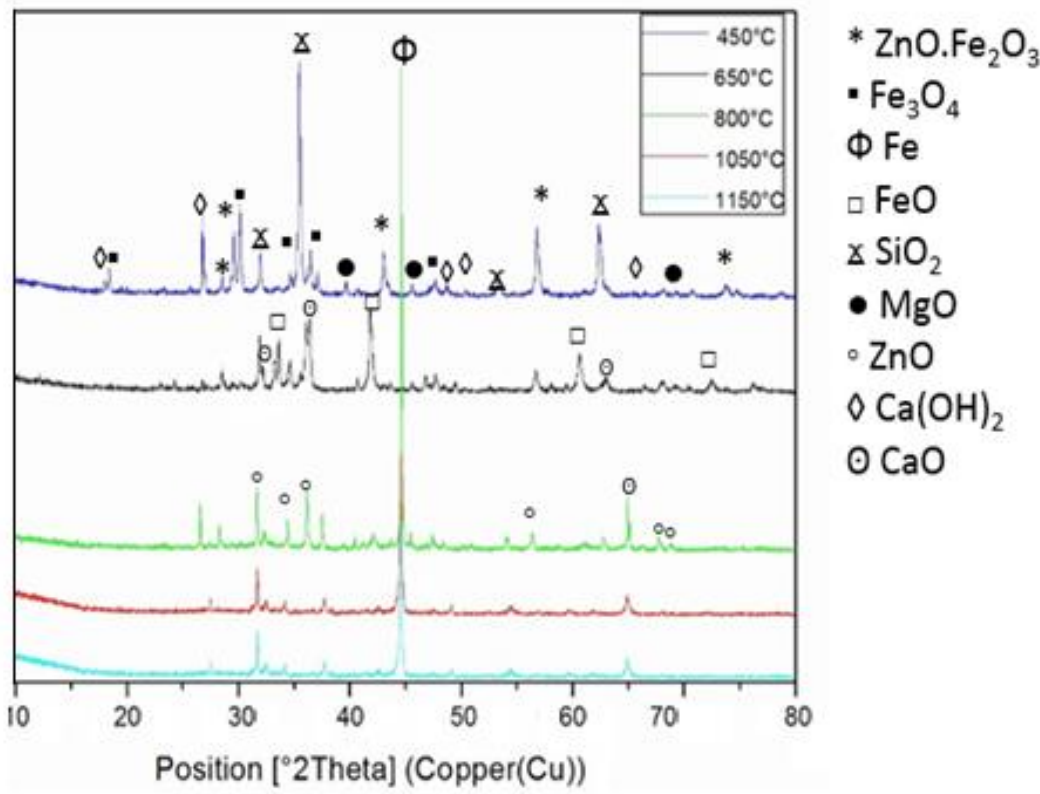

Figure 7: XRD pattern of EAF dust at different carbothermal reduction temperatures. 
3.3. Evaluation of kinetic model for self-reduction Waelz process in temperatures from 450 to $1150^{\circ} \mathrm{C}$.

Figure 8 shows the mass loss in function of the time for carbothermic self-reduction of EAF dust pellets with the reductans at temperatures of $450,650,800,1050$ and $1150^{\circ} \mathrm{C}$.

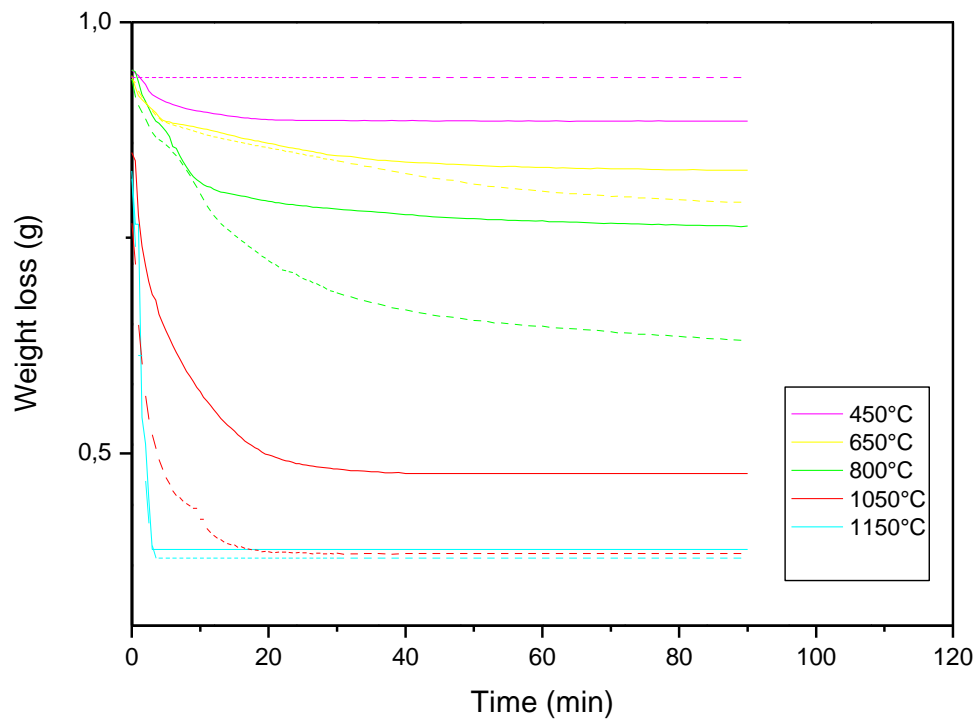

Figure 8: Mass loss of self-reducing pellets in the range of 450 to $1150^{\circ} \mathrm{C}$. (Full line: pellets reduced with petroleum coke; Dash line: pellets reduced with charcoal).

Clearly the carbothermic reduction is influenced by temperature, once weight loss increase with temperature as shown in Figure 8.Figure 9 presents the fractional reaction for pellets reduced with both petroleum coke and charcoal at various temperatures of reduction $\left(450\right.$ to $\left.1150^{\circ} \mathrm{C}\right)$.
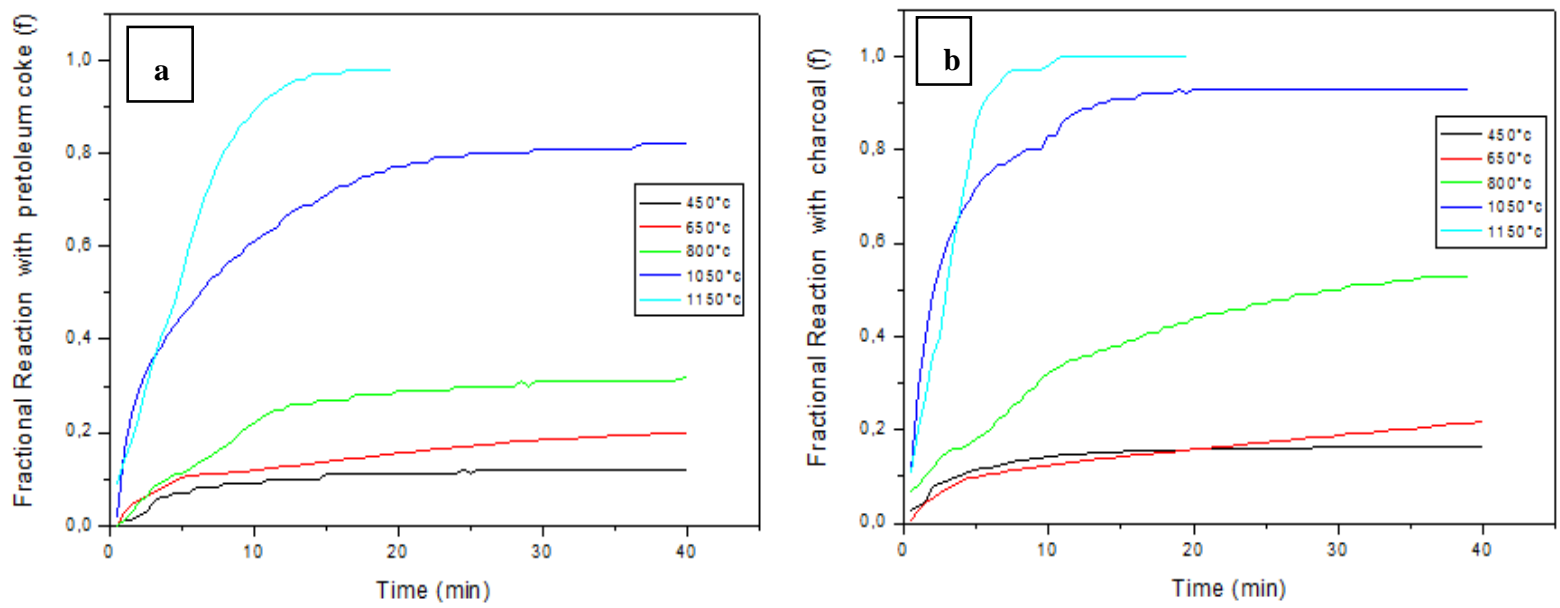

Figure 9: Fractional reaction with temperatures between 450 and $1150^{\circ} \mathrm{C}$ - a) Petroleum coke. b) Charcoal.

It was assumed that the reducing process of EAF dust follows a first-order kinetics and, therefore, the kinetic equation (9) might be

$$
-\ln (1-f)=\text { k.t. }
$$

where $\mathrm{f}$ is the fractional reaction, $\mathrm{t}$ is the reacton time and $\mathrm{k}$ is a pseudo kinetic constant

The Figure 10 presented the kinetic curves for carbothermic reduction of EAF dust at temperatures of 800 , 
1050 and $1150^{\circ} \mathrm{C}$. The adopted kinetic model showed a good fit for the first 20 minutes of reducing reaction.

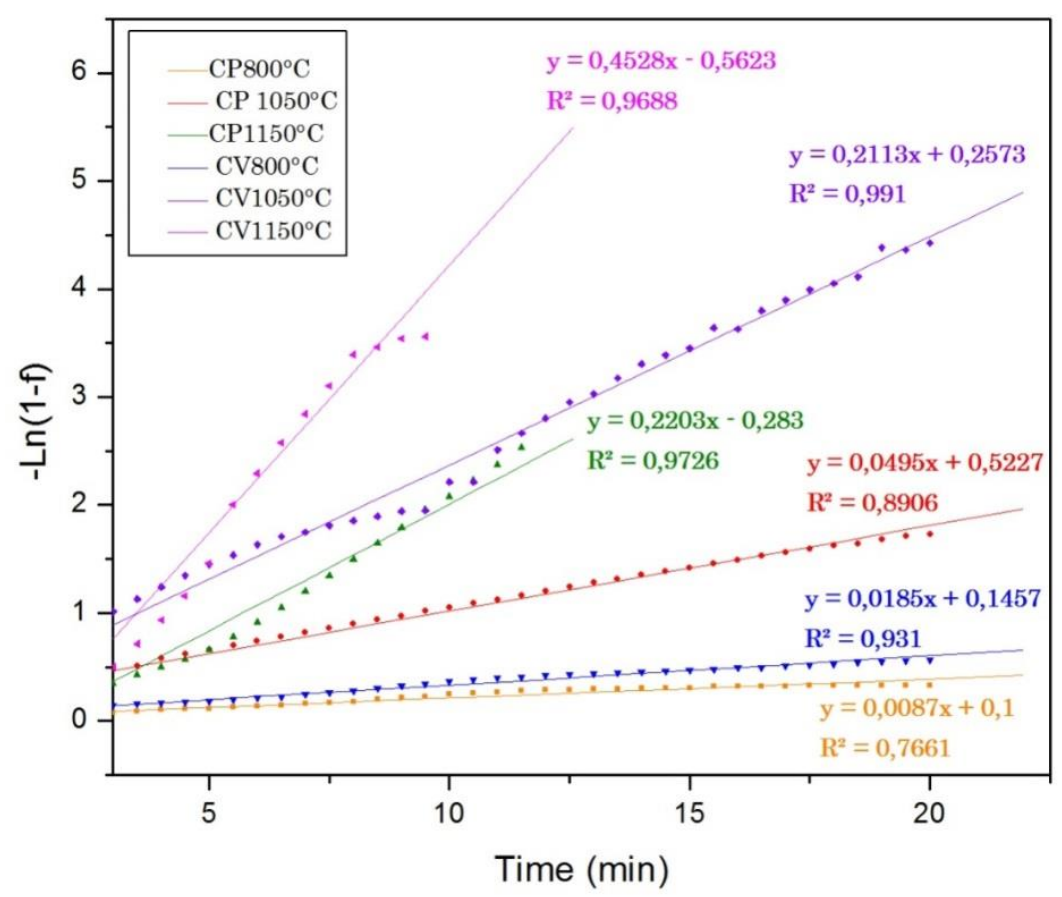

Figure 10: Kinetic carbothermic reduction behavior of PAE (EAF dust) reduced with charcoal, and petroleum coke

Figure 11 presents the Arrhenius plot for reducing reaction with the studied reductants.

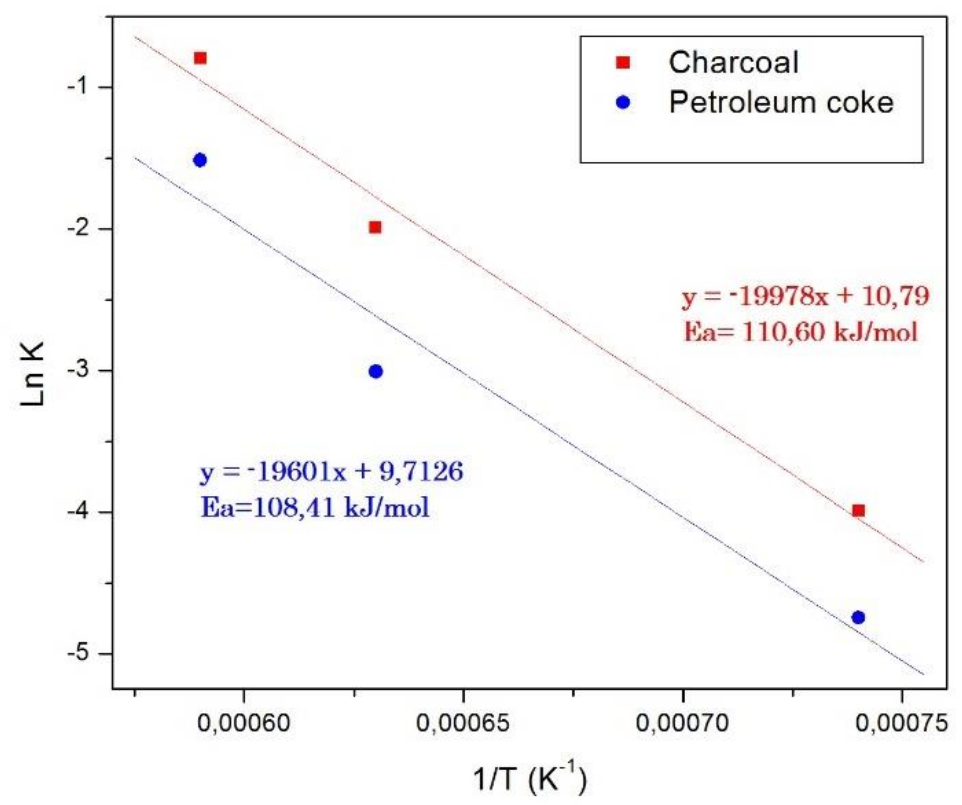

Figure 11: Arrhenius plot for carbothermic reduction of EAF dust using charcoal and petroleum coke.

The apparent activation energies for reduction reactions were $110.60 \mathrm{kcal} / \mathrm{mol}$ and $108.41 \mathrm{~kJ} / \mathrm{mol}$, respectively, for charcoal, and petroleum coke indicating that in both cases the process is controlled by a mixed mechanism with a control tendency toward mass transfer. 
In figure 12 are shown the results of characterization by SEM and EDX for carbothermic reduction at $800^{\circ} \mathrm{C}$, evidencing the presence of thin needles composed basically of $\mathrm{ZnO}$.
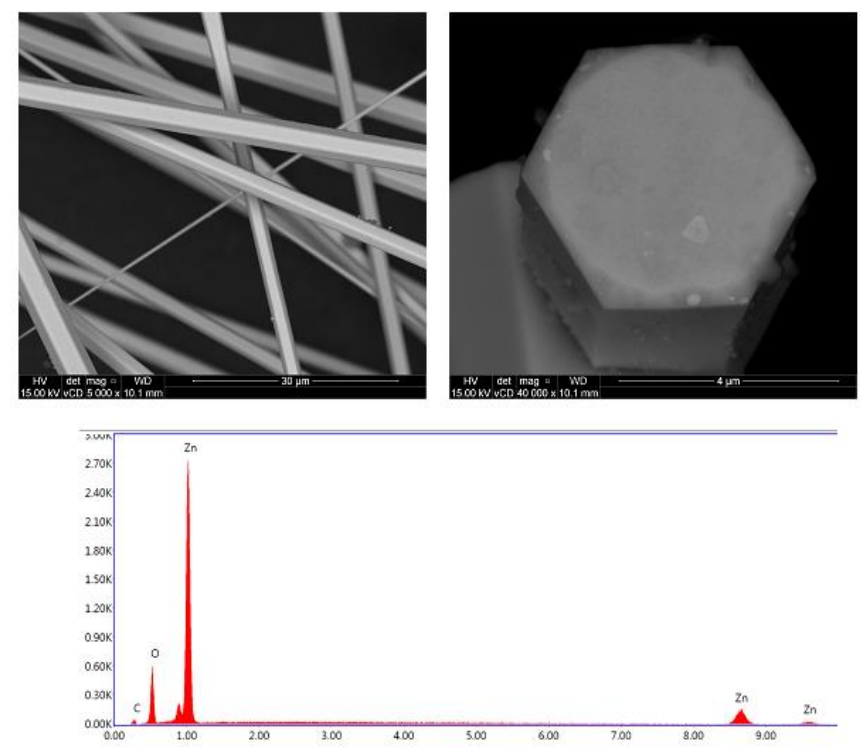

Figure 12: SEM pictures of needles shape structure at 5,000X magnification, showing the hexagonal structure of zinc oxide confirmed by EDX analysis.

\subsection{Evaluation of mechanical behavior of both green and reduced pellets of EAF dust at temperatures from 650 to $1150^{\circ} \mathrm{C}$}

Figure 13-b shows the variation of compressive strength for pellets cured at 1, 3, 7 and 14 days. The compressive strength of pellets must be great also during thehigh temperature carbothermic reduction step, considering the collision between them and the microstructural changes into the rotary furnace. The results of compressive strength for pellets reduced at different temperatures are shown in Figure 13-a.
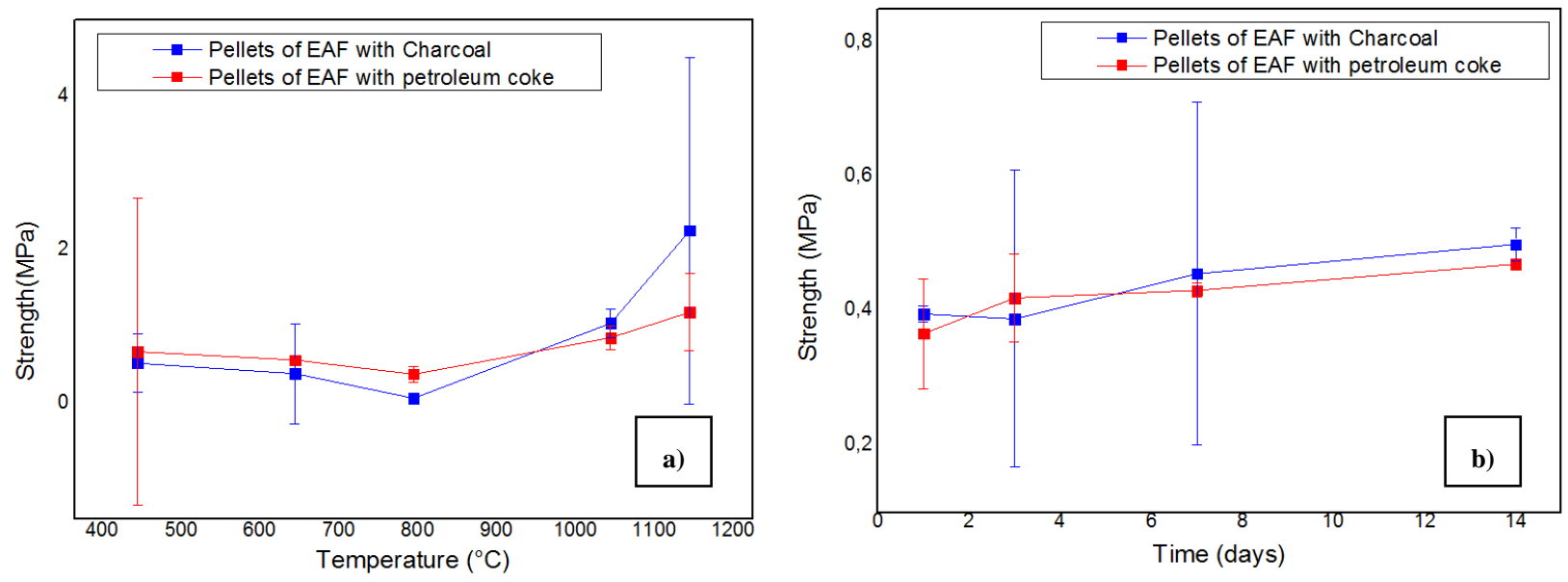

Figure 13: Mechanical behavior of compressive strength for EAF dust pellets reduced with charcoal and petroleum coke. a) Reduced pellets at various temperatures. b) Green pellets as a function of cure time

\subsubsection{Drop tests}

Figure 14 shows the variation of minimum height of fall for breaking the PAE pellets reduced with coal and petroleum coke. Effects of diameter of pellets $(7.5 \mathrm{~mm}, 10.0 \mathrm{~mm}$ and $15.0 \mathrm{~mm})$ and the cure time $(1,3,7$ and 14 days) were analyzed. 

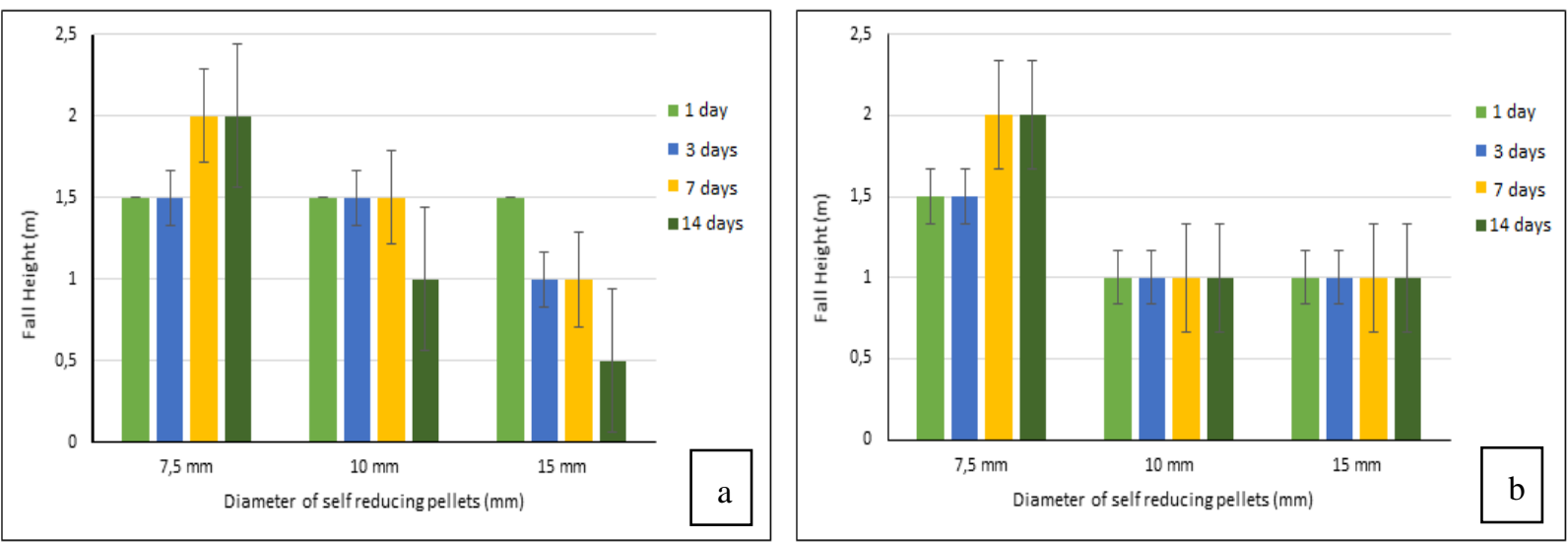

Figure 14:Variation of minimum height for breaking the EAF dust pellets of different diameters over the cure time in days. a) Charcoal. b) Petroleum coke.

\section{DISCUSSION}

Based on results of XRD, SEM images and EDX, chemical and morphological changes were found for pellets reduced with both charcoal or petroleum coke at $450^{\circ} \mathrm{C}$. Hematite particles from raw EAF dust became magnetite at temperatures below $700^{\circ} \mathrm{C}[22,23]$. Increasing the temperature by $200^{\circ} \mathrm{C}$, a percentage of $\mathrm{Fe}_{3} \mathrm{O}_{4}$ reduce to $\mathrm{FeO}$ at temperatures below $800^{\circ} \mathrm{C}$ [10]. At temperatures of $800^{\circ} \mathrm{C}$, reduced pellets showed clearly lead particles.

Kinetic calculations of carbothermic reduction were performed for temperatures from 800 to $1150^{\circ} \mathrm{C}$, because the overall reduction adopted comprises zinc and iron reduction. The main reactions of those reductions take place in this range of temperature. Thus, at the final of the reduction reaction, the solified structure is composed of metallic iron as main phase. The slag phase has wustite $(\mathrm{FeO})$, calcium, magnesium and silicon oxides blends $\left(\mathrm{CaO}, \mathrm{MgO}\right.$ and $\left.\mathrm{SiO}_{2}\right)$ as secondary phases.

Kinetic analysis indicated that the reaction rate increase with the temperature. This finding is supported by others authors $[16,17,24]$, although their reducing reagents or binder were different. Charcoal has high reactivity and faster reaction rate compareted with petroleum coke. However the general behavior of carbothemic reduction are similar.

SEM images of samples reduced at $800^{\circ} \mathrm{C}$ presented a white sheet around the pellet, and small white needles on the support wire, indicating the presence of $\mathrm{ZnO}$, also confirmed by its hexagonal structure clearly seen on figure 12. Zinc oxide might be a reduction product of less stable oxides. The raw dust contain $\mathrm{NiO}$ and $\mathrm{Cu}_{2} \mathrm{O}(0.025 \%$ and $0.231 \%$, respectively, detected by XRF) and those oxides might probably assist the $\mathrm{ZnO}$ formation. At $1050^{\circ} \mathrm{C} \mathrm{ZnO}$ was not found, however at $1150{ }^{\circ} \mathrm{C}$ a small trace of white sheet was found on the support wire, probably due to the high release rate of volatile from the sample at this temperature.

Results of compressive strength presented an addition in resistance of approximately $30 \%$ of the initial resistance for both reductants at 14 days of cure time. Pellets reduced with charcoal showed a compressive strength greater than those reduced with petroleum coke, with a difference of approximately 4 Newtons.

Figure 13a, shows the decrease of resistance in the range of 400 to $800{ }^{\circ} \mathrm{C}$ for pellets reduced with both reductants. Such reduction might be related to the appearance of cracks on the pellet surface causing a fragility of pellets and also by the decomposition of hydroxides at temperatures of about 600 to $900^{\circ} \mathrm{C}$, respectively.

On the range of 800 to $1150{ }^{\circ} \mathrm{C}$ mechanical resistance of pellets after thermal treatment increases, and the more importantmaximum force supported were reachedby pellets made with charcoal,as a result of the formation of iron layers in its state of sintering, obtaining an internal structure of pellet more compact, despite the fact the density of cracks on the surface is high.

For coal pellets synthesized with the first day, the minimum break time is the same for all three diameters, but during the day the resistance of the pads undergoes changes, therefore, the minimum height for breakage pellets $7.5 \mathrm{~mm}$ diameter increases while the beads with $10 \mathrm{~mm}$ diameter remained constant until day 14. Finally, pellets with $15 \mathrm{~mm}$ diameter decreased the minimum height of break due to the amount of mass of each pellet, the diameter and also surface which is in contact with the floor at the moment of impact. 
Pellets prepared with petroleum coke having $7.5 \mathrm{~mm}$ of diameter presented the same behavior of pellets prepared with charcoal. On the other hand, pellets with diameter of 10 and $15 \mathrm{~mm}$ presented a constant minimum height for breaking the samples over the 14 days, although lowest values when compared to values of samples reduced with charcoal.

Charcoal pellets acquire more resistance than pellets with petroleum coke, however, the obtained results regardless the type of reductant, point to pellets of $7.5 \mathrm{~mm}$ as the ideal size for the transportation process of green pellets.

The increased mechanical resistance of pellets with charcoal and petroleum coke are probably related to the calcium hydroxide content, serving as a binder on the particles of raw material, hardening the pellets by the action of $\mathrm{CO}_{2}$, besides the agglomeration of calcium oxide and silica by the formation of hydrated calcium silicates.

The results of compressive strength test for pellets over the 14 days of cure time are great taking into account the demand to carry such material till the rotary kiln of a Waelz process.

\section{CONCLUSIONS}

Carbothermic reduction of pellets of EAF dust, presents a previous phase of oxidation of metallic zinc at $800^{\circ} \mathrm{C}$, assisted by oxygen from less stable metals. For temperatures higher than $800{ }^{\circ} \mathrm{C}$, the decomposition of zinc ferrite to $\mathrm{ZnO}$ and $\mathrm{Fe}_{2} \mathrm{O}_{3}$ takes place and consequently their simultaneous carbothermic reductions.

All results of kinetic calculations indicated the temperature as the main parameter in the carbothermic reduction of EAF dust. The temperature has a remarkable effect on the reduction rate of zinc and iron oxides, and also shows a great importance in the model of chemical reaction, as a limiting factor to control the rate.

Sintered and reduced pellets with charcoal showed a better mechanical behavior at both green and after reduction in all temperatures tested and also presented a greater reaction rate and reduction rate. Estimated activation energy aroound $110 \mathrm{~kJ} / \mathrm{mol}$ indicated that, in both cases (charcoal and petroleum coke), the proceess is controlled by a mixed mechanism with a control tendency toward mass transfer.

\section{ACKNOWLEDGMENTS}

CAPES - PROEX Program / Department of Metallurgy and Materials Engineering - PMT-POLI/USP.

\section{BIBLIOGRAPHY}

[1] U.S. GEOLOGICAL SURVEY, MINERAL COMMODITY SUMMARIES, January 2016, MINERALS.USGS, http://minerals.usgs.gov/minerals/pubs/commodity/zinc/mcs-2016-zinc.pdf, Accessed in December 2016.

[2] ZINC AND SOCIETY, http://www.icz.org.br/site-en/zinc-society.php. Accessed in December 2016.

[3] CANDIAN, N., "Gerenciamineto de Resíduos sólidos da industria siderúrgica", Thesis of M.Sc, Federal University of Minas Gerais, Belo Horizonte, Brazil, 2004.

[4] STEWART, C., "Sustainability in Action : Recovery of Zinc from EAF Dust in the Steel Industry", In: International Lead and Zinc Study Group (ILZSG), Liverpool, England, 2015.

[5] ABNT 10004. "Resíduos Sólidos - Classificação", Associação Brasileira de Normas Técnicas. Rio de Janeiro, Brazil, 2004.

[6] ENVIRONMETAL PROTECTION AGENCY. "Part 261 - Identification Listing of Hazardous Waste". 40CFR, VIII, ChapterI, Unite States, 1998.

[7] GMDI 170. Zweite Allgemeine Verwaltungsvorschrift zum Abfallgesetz, Germany, 1990

[8] JUNCA, E., "Reciclagem de Poeira de Aciaria : Estudo da redução da poeira de aciaria LD , elétrica e ferrita de zinco reciclagem de Poeira de Aciaria", Thesis of D.Sc., University of São Paulo, São Paulo, Brazil, 2014.

[9] GLOBAL STEEL DUST, GSD, http://www.globalsteeldust.com/waelz_kiln_technology. Accessed in December 2016.

[10] BAHGAT, M., KHEDR, M.H. "Reduction Kinetic behavoir and morpholical changes during reduction of magnetite single crystal", Materials Science and Engineering, v. 138, pp. 215-258, 2007.

[11] MANTOVANI, M. C., "Caracterização de poeiras geradas em fornos elétricos a arco e seu estudo quando aglomeradas na forma de pelotas auto-reductoras",Thesis of D.Sc., University of São Paulo, São 
Paulo, Brazil, 1998.

[12] MADÍAS, J., "Reciclado de polvos de horno eléctrico", Revista Acero Latinoamericano, v. 35, pp. 513 $526,2009$.

[13] HUAIWEI, Z., XIN, H. “An overview for the utilization of wastes from stainless steel industries”, Resources, Conservation and Recycling, v.55, pp.745-754, 2011.

[14] PICKLES, C. A., "Thermodynamic analysis of the selective chlorination of electric arc furnace dust", Journal of Hazardous Materials, v.166, pp. 1030-1042, 2009

[15] RUIZ, O., CLEMENTE, C., ALONSO, M., ALGUACIL, F. J.,. "Recycling of an electric arc furnace flue dust to obtain high grade ZnO”, Journal of Hazardous Materials, v.141, pp. 33-36, 2007.

[16] OSINGA, T., OLALDE, G., STEINFELD, A . "Solar Carbothermal Reduction of ZnO : Shrinking Packed-Bed eactor Modeling and Experimental Validation”, American Chemical Society, v. 43, n. 25, pp. 7981-7988, 2004.

[17] MARROQUÍN, M.G., "Caracterizacao Cinética da Reducao de Ferrita de Zinco presente em Poeiras de Aciaria, por Misturas CO- $\mathrm{CO}_{2}$ ”, Thesis of D.Sc., Federal University of Rio de Janeiro, Rio de Janeiro, Brazil,2008.

[18] PICKLES C. A., "Reaction of electric arc furnace dust with molten iron containing carbon and silicon", Transactions I \& SM, pp. 55- 67, 2002.

[19] HONG, L., SOHN, H. Y., SANO, M., "Kinetics of carbothermic reduction of magnesia and zinc oxide by thermogravimetric analysis technique”, Journal of Metallurgy, pp. 171-176, 2003.

[20] ROSENQVIST, T., Principles of Extractive Metallurgy. 2 ed., [s.1], 2004

[21] LIN, X., PENG, Z., YAN, J., LI, Z., HWANG, J. Y., et al., "Pyrometallurgical recycling of electric arc furnace dust”, Journal of Cleaner Production, v. 149, pp. 1079-1100, 2017.

[22] MACHADO, J. G. M. da S., "Estudo de caracterização e avaliação da influência do tempo na redução carbotérmica do pó de aciaria elétrica", Thesis of M.Sc., Federal University of Rio Grande do Sul, Porto Alegre, Brazil, 2008.

[23] SHIMOKAWABE, M., FURUICHI, R., PASQUEVICH D.M. "Influence of the Preparation history of alfa-hematita on its reactivity for hidrogen reduction",Thermochimica Acta, v. 28, 1979.

[24] LEE, J., LIN, C., \& CHEN, H., “Carbothermal Reduction of Zinc Ferrite”, Metallurgical and Materials Transactions B, v.32, pp. 1033-1040, 2001.

[25] ASTM E382 - 12 "Standard Test Method for Determination of Crushing Strength of Iron Ore Pellets"

[26] ASTM D3174-11 "Standard Test Method for Ash in the Analysis Sample of Coal and Coke from Coal"

[27] ASTM D3173-11 "Standard Test Method for Moisture in the Analysis Sample of Coal and Coke"

[28] ASTM D3175-11 "Standard Test Method for Volatile Matter in the Analysis Sample of Coal and Coke" 